\title{
KEARIFAN LOKAL BANJAR DALAM KUMPULAN CERPEN GALUH PASAR TERAPUNG KARYA HATMIATI MASY'UD (KAJIAN ETNOGRAFI)
}

\author{
Fajarika Ramadania, Jamilah \\ Program Studi Pendidikan Bahasa dan Sastra Indonesia \\ STKIP PGRI Banjarmasin, Universitas Terbuka Banjarmasin \\ baikhati27@gmail.com,jamilah-bjm@ecampus.ut.ac.id \\ Received: Oktober 2018; Accepted: Juni 2019; Published: Juni 2019
}

\section{ABSTRACT}

This research of local wisdom Banjar above Colection History Galuh Pasar Terapung creator Hatmiyati Masy'ud. The function is (1) describe language, (2) colecting job descrition population, (3) colection system organization social, (4) describe system religi. The methode research etnografi and methode kepustakaan. Analysis methode analysis descriptif and analysis essay. The result research is (1) local wisdom Banjar above history with language. (2) The analysis job description. (3) The analysis the system organization social. (4) The analysis system religi.

Key word: local wisdom Banjar; history; etnografi

\section{ABSTRAK}

Penelitian ini berkenaan dengan Kearifan Lokal Banjar dalam Kumpulan Cerpen Galuh Pasar Terapung karya Hatmiati Masy'ud. Tujuan penelitian ini adalah untuk: (1) mendeskripsikan bahasa yang digunakan, (2) memaparkan mata pencaharian penduduk, (3) mengemukakan sistem organisasi sosial, (4) mendeskripsikan sistem religi. Pendekatan yang digunakan adalah pendekatan etnografi. Jenis penelitian yang digunakan adalah kepustakaan. Metode yang digunakan dalam penelitian ini adalah metode deskriptif analisis dan analisis isi. Hasil dari penelitian ini adalah (1) Hasil analisis kearifan lokal Banjar dalam kumpulan cerpen Galuh Pasar Terapung yang berkenaan dengan bahasa. (2) Hasil analisis kearifan lokal Banjar dalam kumpulan cerpen Galuh Pasar Terapung yang berkenaan dengan mata pencaharian. (3) Hasil analisis kearifan lokal Banjar dalam kumpulan cerpen Galuh Pasar Terapung yang berkenaann dengan sistem organisasi sosial. (4) Hasil analisis kearifan lokal Banjar dalam kumpulan cerpen Galuh Pasar Terapung yang berkenaan dengan sistem religi.

Kata kunci: kearifan lokal banjar; cerpen; etnografi

\section{PENDAHULUAN}

Banyak ragam sastra yang dihasilkan oleh para sastrawan atau penulis salah satunya adalah cerita fiksi. Sebagai sebuah karya imajinasi, cerita fiksi menawarkan berbagai permasalahan manusia dan kemanusiaan, hidup dan kehidupan, pengarang menghayati berbagai permasalahan tersebut dengan penuh kesungguhan yang kemudian diungkapannya kembali melalui sarana fiksi sesuai dengan pandangannya.Salah satu contoh karya fiksi adalah Galuh Pasar Terapung. Banyak ragam sastra yang dihasilkan oleh para sastrawan atau penulis salah satunya adalah cerita fiksi. Sebagai sebuah karya imajinasi, cerita fiksi menawarkan berbagai permasalahan manusia dan kemanusiaan, hidup dan kehidupan, pengarang menghayati berbagai permasalahan tersebut dengan penuh kesungguhan yang kemudian 
diungkapannya kembali melalui sarana fiksi sesuai dengan pandangannya.Salah satu contoh karya fiksi adalah Galuh Pasar Terapung.

Kumpulan cerpen Galuh Pasar Terapung adalah fiksi yang menceritakan tentang masyarakat Banjar. Alur dan latar kisah ini sengaja ditampilkan pengarangnya seperti adanya untuk menghidupkan tokoh dan memberi kearifan khas tentang keanekaragaman kejadian yang terjadi di masyarakat Banjar Kalimantan Selatan. Meskipun begitu, cerita dalam buku ini fiktif seluruhnya.

\section{PEMBAHASAN}

\subsection{Kearifan Lokal Banjar}

Zaidan

menjelaskan, Istilah kearifan lokal juga dapat disamakan dengan kearifan daerah atau kearifan etnis. Semua berkait dengan budaya lokal, budaya tradisional, budaya daerah, dan budaya etnis. Istilah lain yang juga sering digunakan sebagai kearifan lokal adalah corak setempat kearifan tempatan, atau local colour (Inggris), atau coucar local (Prancis).

Pengertian sastra kearifan lokal adalah gambaran daerah terlalu seperti pakaian, sopan santun, dialek yang melatari kehidupan tokoh dalam karya sastra dan hanya bersifat dekoratif. Kearifan tempatan, misalnya Minangkabau dalam beberapa novel Balai Pustaka.

Purba (2009) menjelaskan, "Sastra kearifan tempatan adalah penggambaran, corak atau ciri khas suatu masa atau daerah tertentu serta pemakaian bahasa atau kata-kata daerah yang bersangkutan dengan tujuan kisahan menjadi lebih menarik dan keasliannya lebih tampak. Sikap dan lingkungan juga ikut mendukung corak setempat".
Purba (2009) Sastra kearifan lokal pada hakikatnya adalah realitas sosial budaya suatu daerah yang ditunjuk secara langsung oleh fiksionalitas suatu karya sastra. Secara intrinsik dalam struktur karya sastra kearifan lokal selalu dihubungkan dengan unsur-unsur pembangkitannya, yaitu latar belakang penokohan, gaya bahasa, dan suasana. Dalam kontek sastra sebagai sistem tanda, kearifan lokal selalu dikaitkan dengan kenyataan hidup, yaitu kenyataan sosial budaya secara luas. Komponenkomponennya antara lain adat istiadat, agama, kepercayaan, sikap, filsafat hidup, hubungan sosial, struktur sosial atau sistem kekerabatan.

Jadi, kearifan lokal adalah wana dari daerah itu sendiri yang berkaitan dengan budaya yang bersifat tradisional, lokal, daerah, dan etnis. Baik sekiranya jika kearifan lokal sangat berkaitan satu sama lain dengan pendengkatan yang bersifat etnografi. Etnografi adalah ilmu yang mempelajari masyarakat dari kultur budaya lokal masyarakat dari segi tradisionalnya yang masih sangat kental.

\subsection{Kajian Etnografi}

Endraswara (2008:107)

menjelaskan, "Kajian etnografi sebenarnya termasuk ke dalam penelitian antropologi sastra melalui kajian Etnografi". Peneliti dapat mengungkap berbagai hal yang berhubungan dengan kehidupan manusia. Hal tersebut dilakukan mengingat (cukup) banyak karya sastra - termasuk prosa fiksi - yang memuat aspek-aspek etnografi yang berkaitan denga kehidupan manusia, khususnya aspek-aspek yang berkaitan dengan budaya suatu masyarakat. Lewat kajian etnografi 
dapat dideskripsikan mengenai kebudayaan suatu masyarakat.

Sulistyowati dan Tarsyad (2015:83) mengemukakan pendapat sebagai berikut. Pada kajian etnografi, peneliti dapat misalnya memusatkan kajiannya khusus mengenai kebudayaan suatu masyarakat yang termuat dalam prosa fiksi. Budaya masyarakat yang tergambar dalam prosa fiksi diungkap sampai pada sarana estetiknya. Dengan demikian kajian etnografi pada prosa fiksi selain mendeskripsikan kebudayaan suatu masyarakat, juga memberikan gambaran berdasarkan sarana estetika yang tidak terlepas dari bahasa sastra yang diungkap melalui prosa fiksi yang tengah dikaji.

\subsection{Cerpen}

Nurgiantoro

menjelaskan, "Cerpen merupakan bentuk karya sastra yang sekaligus disebut fiksi, cerpen adalah sebuah cerita yang selesai di baca dalam sekali duduk, kira-kira berkisar antara setengah sampai dua jam suatu hal yang tak mungkin dilakukan untuk sebuah novel".

Semi (Rizka, 2011:5) menjelaskan, cerpen adalah karakter yang dijabarkan lewat rentetan kejadian dari pada kejadian-kejadian itu sendiri satu-persatu serta menunjukkan ke (satu, beberpa arah), dan arah yang lainnya. Arah yang berisi pengarang tadi harus dijajaki sendiri oleh pembaca, dia cernakan lebih lanjut dalam benaknya, menurut gaya dan pemikirannya sendiri.

\section{METODE PENELITIAN}

Pendekatan yang di gunakan dalam penelitian "Kearifan Lokal Banjar dalam Kumpulan Cerpen Galuh Pasar Terapung Karya Hatmiati Masy'ud (Kajian
Etnografi)" adalah pendekatan tekstual, yang mengkaji kearifan lokal Banjar dalam dalam kajian etnografi karya sastra. Untuk mengkaji atau menganalisis karya sastra bisa digunakan beberapa pendekatan dalam penelitian ini. Peneliti hanya menggunakan pendekatan etnografi. Pendekatan etnografi adalah suatu pendekatan yang menelaah atau mempelajari tentang kebudayaan suatu suku masyarakat.

Jenis penelitian yang digunakan peneliti adalah jenis penelitian kepustakaan. Penelitian ini berusaha memecahkan masalah dengan mendeskripsikan data yang terdapat dari subjek. Hal ini didasarkan pada pertimbangan bahwa peneliti ingin memahami, mengkaji secara mendalam serta memaparkannya dalam tulisan ini mengenai kebudayaan yang terdapat di Daerah Kalimantan. Karena tujuan tersebut, maka relevan jika penelitian ini peneliti menggunakan jenis penelitian kepustakaan dan kualitatif. Penelitian ini menggunakan metode deskriptif analisis. Dalam metode deskriptif analisis peneliti disini ingin mengkaji dan meneliti data secara obyektif berdasarkan fakta nyata yang di temukan dalam kumpulan cerita pendek Galuh Pasar Terapung karya Hatmiati Masy'ud, kemudian di paparkan secara deskriptif yang lebih mengutamakan proses daripada hasil. Kemudian metode yang selanjutnya adalah metode analisi isi. Dalam karya sastra, analisis isi yang dimaksud peneliti adalah pesan-pesan, yang dengan sendirinya sesuai dengan hakikat sastr, dan dengan dasar pelaksanaan metode deskriptif analisis ini memberikan perhatian pada isi pesan. Ratna (2015:53) 
menjelaskan, "Metode penelitian dapat juga diperoleh melalui gabungan metode, dengan syarat kedua metode tidak bertentangan". Oleh karena itulah, metode deskriptif analisis juga dapat digabungan dengan analisis isi karena, mulamula data dideskripsikan, dengan maksud untuk menemukan unsurunsurnya, kemuadian dianalisis berdasarkan subjek yang ditemukan.

Data yang digunakan dalam penelitian ini berasal dari berbagai sumber tertulis yang mendukung keperluan penelitian. Sedangkan sumber utama data penelitian ini adalah buku berjudul Galuh Pasar Terapung karya Aliansyah Jumbawuya dan Hatmiati Masy'ud, terdiri dari 14 kumpulan cerpen. 14 kumpulan cerpen Galuh Pasar Terapung karya Aliansyah Jumbawuya dan Hatmiati Masy'ud. Peneliti sudah membatasi objek yang akan dikaji, yang hanya peneliti fokuskan pada 7 cerpen dalam kumpulan cerpen Galuh Pasar Terapung, yakni (1) Buaya Muara, (2) Alkah, (3) Aku Sayang Ibu dan Ayahku, (4) Pukul Satu Dinihari, (5) Mereka yang Bertahan, (6) Piring Ibu, dan (7) Mari Kita Jalan Bersama.

Adapun subjek data dalam penelitian ini adalah satuan cerita pendek dalam kumpulan cerpen Galuh Pasar Terapung Karya Aliansyah Jumbawuya dan Hatmiati Masy'ud, yang berupa: (1) bahasa dalam kumpulan cerpen Galuh Pasar Terapung, (2) mata pencaharian yang terdapat dalam kumpulan cerpen Galuh Pasar Terapung, (3) sistem organisasi sosial yang terdapat dalam kumpulan cerpen Galuh Pasar Terapung, (4) sistem religi yang terdapat dalam kumpulan cerpen Galuh Pasar Terapung.
Data dikumpulkan melalui penelitian ini penulis menggunakan metode telaah kepustakaan. Yaitu meneliti buku yang ada kaitannya dengan pembahasan skripsi ini, dan juga pengumpulan melalui dokumentasi atau studi pustaka, yaitu mengumpulkan semua bahan tertulis yang berhubungan dengan objek penelitian, kemudian mengobservasi bahan tertulis tersebut. Dalam penelitian ini peneliti menggunakan instrumen penelitian untuk memudahkan peneliti dalam menjaring data dalam bahasan yang ada pada kumpulan cerpen Galuh Pasar Terapung karya Hatmiati Masy'ud.

\section{HASIL DAN}

PEMBAHASAN

\subsection{Analisis Kearifan Lokal Banjar dalam Cerpen Buaya Muara \\ 3.1.1 Sinopsis Cerpen Buaya Muara}

Maradina adalah seorang gadis yang tinggal di Desa Muara, ia adalah seorang gadis yang cantik. Sampai dimana ia jatuh cinta dengan pemuda bernama Irwan yang baru kembali dari perantauan. Maradina adalah teman masa kecil Irwan yang telah menjelma menjadi gadis jelita.

Maradina menjadi gila karena perbutan Irwan dan teman-temannya. Dan ia memutuskan untuk membalas dendam akan perbuatan keji mereka terhadap Maradina. Maradina dikurung dikerangkeng karena sering mengamuk tanpa sebab.

Irwan adalah korban pertama Maradina, Irwan mati karena disambar oleh makhluk besar peliharaan Maradina yaitu seekor buaya. Maradina yang geram mulai membunuh teman-teman Irwan dengan bergiliran. Sampai dimana warga mengundang pawang buaya 
untuk menghentikan gugurnya korban, tetapi itu tidak bisa menghentiakan kesakitan hati Maradina. Ia tetap memangsa temanteman Irwan secara bergiliran.

Tiba saatnya tinggal satu korban lagi yang harus dibereskan. Salman adalah korban terakhir Maradina yang memutuskan untuk berserah diri kepada yang Maha Kuasa dan mendatangi Maradina untuk meminta maaf. Makhluk besar itupun semakin dekat dengan Salman dan kemudian mundur dengan pelan seiring robohnya Maradina.

\subsubsection{Analisis Bahasa dalam} Cerpen Buaya Muara

a. Bahasa Banjar

1. Mata Maradina serupa bara, lindap dalam

kerangkeng. (01/BM/BHS/HM, 2016:03).

2. tubuhnya yang dulu sintal kini tinggal kulit pembalut tulang, kulit putih kuning yang dulu selalu dipuja setiap orang kini telah keriput, meskipun bukan dimakan usia, tetapi karena Maradina telah memutuskan gila. (01/BM/BHS/HM, 2016:03).

3. Subuh kali ini ditemani hujan gerimis, Maradina meringkuk, sehelai tapih bahalai menyelimuti tubuhnya yang ringkih. (01/BM/BHS/ HM, 2016:04).

4. Maradina dibaringkan di sebuh tilam tipis tengah rumah, ibu dengan hati-hati menyeka tubuh anak gadisnya. (01/BM/BHS/ HM, 2016:04).
5. Bertangguk-tangguk mata itu menatap ruang tengah di mana Maradina sedang duduk menghadapi nasi dan segelas air minum. Ibu diam tanpa suara. (01/BM/BHS/HM, 2016:05)

6. Tiga orang, Salman, Jali, dan Rusli bersepakat pergi. Mereka akan meninggalkan kampung Muara. Meninggalkan sanak saudara dan handai taulan. (01/BM/BHS/ HM, 2016:09).

7. Mereka hanya mengatakan untuk mencari pekerjaan di kota karena di desa mereka humahuma sudah terjual, kebun karet sudahh dibabat untuk penambangan batu bara, sedangkan sungai, saat ini sudah penuh limbah sehingga ikan-ikannya oun enggan utuk berenang di situ. (01/BM/SBHS/bsd/HM, 2016:09).

8. Lating berjalan pelan, tukang getetk terus berpegangan pada tali untuk menarik getek sampai ke seberang. (01/BM/BHS/ /HM, 2016:10).

b. Bahasa Arab

1. Suara azan di mushala terdengar jelas sampai rumah Maradina. (01/BM/BHS/ HM, 2016:13).

Berdasarkan kutipan dalam cerpen Buaya Muara karya Hatmiati Masy'ud terdapat Bahasa Banjar dan Bahasa Arab. Sejauh yang dapat dikaji, tampaknya pengarang banyak menggunakkan kosa-kata bahasa Banjar dan bahasa Arab. Ditemukan 7 bahasa Banjar antara lain: lindap (kilat/sambaran), sintal (kenyal), tapih bahalai (kain yang panjangnya 1.5 meter yang sering dipakai masyarakat Banjar ketika tidur), tilam (kasur tipis), huma-huma (sawah), lanting (rakit), dan bertangguk- 
tangguk (banyak/sangat banyak), dan 2 bahasa Arab antara lain: azan (penanda datangnya waktu shalat) dan mushala (tempat beribadah bagi umat islam).

\subsubsection{Analisis Mata Pencaharian dalam Cerpen Buaya Muara}

a. Polisi

Polisi merupakan badan pemerintahan yang bertugas memelihara keamanan dan ketertiban umum biasanya menangkap orang yang melanggar hukum dan yang menegakan hukum diseluruh wilayah negara. Kepolisian adalah salah satu lembaga penting yang memainkan tugas utama sebagai penjaga keamanan, ketertiban dan penegakan hukum, sehingga lembaga kepolisian pasti lah ada di seluruh negara berdaulat. Kadangkala pranata ini bersifat militaristis, seperti di Indonesia sebelum Kepolisian Negara Republik Indonesia (POLRI) dilepas dari ABRI. Polisi dalam lingkungan pengadilan bertugas sebagai penyidik. Dalam tugasnya dia mencari barang bukti, keterangan-keterangan dari berbagai sumber, baik keterangan saksi-saksi maupun keterangan saksi ahli Seperti yang terdapat dalam cerpen Buaya Muara, perhatikan kutipan berikut.

"Pak, bagaimana kalau kita

laporkan ke kepolisian saja"

Suara Haji Ridwan terdengar

di tengah kerumunan.

(01/BM/MP/HM, 2016:07).

\section{b. Pawang Buaya}

Pawang adalah orang yang memiliki keahlian yang istimewa yang berkaitan dengan ilmu gaib, seperti dukun, mualim perahu, pemburu buaya, penjinak ular. Pawang Buaya adalah orang yang pandai menangkap atau menjinakan buaya. Seperti yang terdapat dalam cerpen Buaya Muara, perhatikan kutipan berikut.

"Iya Pak Haji, kemarin kita sudah sampaikan. Mungkin esok mereka sudah datang membantu untuk menangkap buaya itu. Kabarnya mereka akan membawa pawang buaya ke sini". (01/BM/MP/HM, 2016:07).

Berdasarkan kutipan dalam cerpen Buaya Muara karya Hatmiati Masy'ud terdapat 2 mata pencaharian yaitu: Polisi dan Pawang Buaya. Jadi dapat disimpulakan bahwa pengarang tidak begitu banyak menjelaskan tentang profesi atau pekerjaan tokoh-tokoh yang disebutkan dalam cerpen Buaya Muara.

3.1.4 Analisis Sistem Organisasi Sosial dalam Cerpen Buaya Muara a. Kepala Desa

Kepala desa adalah sebutan pemimpin desa di Indonesia. Kepala desa merupakan pimpinan tertinggi dari pemerintah desa. Masa jabatan kepala desa adalah 6 (enam) tahun, dan dapat diperpanjang lagi untuk 3 (tiga) kali masa jabatan berikutnya berturut-turut atau tidak. Kepala desa tidak bertanggung jawab kepada Camat, namun hanya dikoordinasikan saja oleh Camat. Seperti yang terdapat dalam cerpen Buaya Muara, perhatikan kutipan berikut.

Kepala desa kampung muara memanggil warganya untuk mengadakan rapat. Saat ini telah berkumpul sekitar 50 orang. (01/BM/SOS/HM, 2016:06).

b. Polisi

Polisi merupakan badan pemerintahan yang bertugas memelihara keamanan dan ketertiban umum biasanya menangkap orang yang melanggar hukum dan yang menegakan hukum diseluruh wilayah 
negara. Kepolisian adalah salah satu lembaga penting yang memainkan tugas utama sebagai penjaga keamanan, ketertiban dan penegakan hukum, sehingga lembaga kepolisian pasti lah ada di seluruh negara berdaulat. Kadangkala pranata ini bersifat militaristis, seperti di Indonesia sebelum Kepolisian Negara Republik Indonesia (POLRI) dilepas dari ABRI. Polisi dalam lingkungan pengadilan bertugas sebagai penyidik. Dalam tugasnya dia mencari barang bukti, keterangan-keterangan dari berbagai sumber, baik keterangan saksi-saksi maupun keterangan saksi ahli Seperti yang terdapat dalam cerpen Buaya Muara, perhatikan kutipan berikut.

"Pak, bagaimana kalau kita laporkan ke kepolisian saja" Suara Haji Ridwan terdengar di tengah kerumunan.

(01/BM/SOS/HM, 2016:07).

Berdasarkan kutipan dalam cerpen

Buaya Muara karya Hatmiati

Masy'ud terdapat 2 sistem organisasi sosial yaitu: kepala desa dan Polisi.

\subsubsection{Analisis Sistem Religi dalam Cerpen Buaya Muara \\ a. Pakaian Kuning}

Pakaian kuning adalah pakaian yang sering digunakan dalam upacara ilmu gaib yang biasanya memakai baju kuning, celana kuning dan topi kuning. Seperti yang terdapat dalam cerpen Buaya Muara, perhatikan kutipan berikut.

Pagi itu, segerombolan warga telah berada di tepi sungai, seorang pawang buaya dengan pakaian kuning telah siap di tepi sungai. (01/BM/SRL/HM, 2016:08).

\section{b. Sesajen dan Mantra}

Sajen adalah makanan (bunga-bunga dsb) yang disajikan kepada orang halus untuk sembah. Sesajen juga sering digunakan untuk sejenis persembahan kepada dewa atau arwah nenek moyang pada upacara adat di kalangan penganut kepercayaan kuno di Indonesia Mantra adalah perkataan atau ucapan yang memiliki kekuatan gaib (misal dapat menyembuhkan, mendatangkan celaka, dsb), upacara itu dimulai dengan pembacaan, susunan kata berunsur puisi (seperti rima, irama) yang dianggap mengandung kekuatan gaib, biasaya diucapkan oleh dukun atau pawang untuk menandingi kekuatan gaib yang lain. Seperti yang terdapat dalam cerpen Buaya Muara, perhatikan kutipan berikut.

Beberapa sesajen berada di depan pawang itu yang sedari tadi duduk bersila dengan mata terpejam dan mulut komat-kamit merapal mantra. (01/BM/SRL/HM, 2016:08-09).

\section{c. Kain Kuning}

Kain kuning adalah kain yang berkearifan kuning yang bisa dipakai untuk hal-hal yang berbau gaib. Seperti yang terdapat dalam cerpen Buaya Muara, perhatikan kutipan berikut.

Di kerangkeng, Maradina bersidekap, kain kuning di tangannya telah basah oleh keringat. (01/BM/SRL/HM, 2016:09).

\section{d. Kopi Pahit dan Kopi Manis}

Kopi pahit adalah kopi yang tidak dibubuhi gula, kopi manis adalah kopi yang dibubuhi gula sesuai kebutuhan, kopi pahit dan kopi manis juga digunakan untuk hal-hal yang berbau gaib sebagai persembahan kepada makhluk halus. Seperti yang terdapat dalam cerpen Buaya Muara, perhatikan kutipan berikut. 
Dua cangkir kopi pahit dan kopi

pahit telah hilang baunya. (01/BM/SRL/HM, 2016:09).

\section{e. Kemenyan}

Kemenyan atau bisa juga disebut dupa berasal dari tumbuahn Stryrax benzolin, yang harum baunya ketika dibakar. Kemenyan di cerpen Buaya Muara digunakan untuk mengundang makhluk gaib. Seperti yang terdapat dalam cerpen Buaya Muara, perhatikan kutipan berikut.

Pawang buaya terdiam. kemenyan menyesakkan nafas. (01/BM/SRL/HM, 2016:10).

\section{f. Kelambu Kuning}

Kelambu atau tirai (tempat tidur dsb) dari kain kasa untuk mencegah nyamuk. Kelambu kuning biasanya digunakan untuk meletakkan barang-barang yang dianggap keramat dan mempunyai kekuatan gaib. Seperti yang terdapat dalam cerpen Buaya Muara, perhatikan kutipan berikut.

Suatu malam, Maradina membuka kamar ayahnya, sebuah kelambu kuning di pojok telah menarik perhatiannya. (01/BM/SRL/HM, 2016:11).

\section{g. Ritual Makhluk Besar Ritual atau ritus adalah} upacara keagamaan. Ritual makhluk besar di cerpen Buaya Muara adalah ritual yang dapat mendatangkan makhluk besar dari alam gaib yang dapat diperintah oleh orang yang menjalankan ritual. Seperti yang terdapat dalam cerpen Buaya Muara, perhatikan kutipan berikut. Sebuah buku catatan kumal tulisan tangan ayahnya tentang ritual makhluk besar pelan-pelan dipelajarinya. (01/BM/SRL/HM, 2016:11).

Berdasarkan kutipan dalam cerpen Buaya Muara karya Hatmiati Masy'ud terdapat 8 sistem religi yaitu: pakaian kuning, sesajen, , merapal mantra, kain kuning, kopi pahit dan kopi manis, kemenyan, kelambu kuning, dan ritual makhluk besar. Dapat disimpulkan pengarang banyak memasukan hal-hal yang berbau gaib karena dalam judul cerpennya sendiri kita dapat mengetahui bahwa cerpen ini sangat kental akan kepercayaannya terhadap makhluk gaib, jadi tidak diherankan kenapa pengarah banyak menggunakan kosa-kata berbau alam gaib.

\section{Tabel 1}

\section{Hasil Analisis Bahasa cerpen}

\begin{tabular}{|c|c|c|c|}
\hline No & Kode Data & Indikator & Interpretasi \\
\hline 1 & $\begin{array}{l}\text { (01/BM/BHS/HM, } \\
\text { 2016:03) }\end{array}$ & lindap & kilat/sambaran \\
\hline 2 & $\begin{array}{l}\text { (01/BM/BHS/HM, } \\
\text { 2016:03) }\end{array}$ & sintal & kenyal \\
\hline 3 & $\begin{array}{l}\text { (01/BM/BHS/ } \\
\text { HM, 2016:04) }\end{array}$ & $\begin{array}{l}\text { tapih } \\
\text { bahalai }\end{array}$ & kain panajang \\
\hline 4 & $\begin{array}{l}\text { (01/BM/BHS/ } \\
\text { HM, 2016:04) }\end{array}$ & tilam & kasur \\
\hline 5 & $\begin{array}{l}\text { (01/BM/BHS/ } \\
\text { HM, 2016:05) }\end{array}$ & $\begin{array}{l}\text { huma- } \\
\text { huma }\end{array}$ & sawah \\
\hline 6 & $\begin{array}{l}\text { (01/BM/BHS/ } \\
\text { HM, 2016:09) }\end{array}$ & lanting & rakit \\
\hline 7 & $\begin{array}{l}\text { (01/BM/BHS/ } \\
\text { HM, 2016:09) }\end{array}$ & $\begin{array}{l}\text { bertanguk- } \\
\text { tangguk }\end{array}$ & $\begin{array}{c}\text { banyak/sangat } \\
\text { banyak }\end{array}$ \\
\hline 8 & $\begin{array}{l}\text { (01/BM/BHS/ } \\
\text { HM, 2016:13) }\end{array}$ & azan & $\begin{array}{c}\text { penanda } \\
\text { waktu shalat }\end{array}$ \\
\hline 9 & $\begin{array}{l}\text { (01/BM/BHS/ } \\
\text { HM, 2016:13) }\end{array}$ & mushala & $\begin{array}{c}\text { tempat } \\
\text { beribadah }\end{array}$ \\
\hline
\end{tabular}

\section{KESIMPULAN}

Berdasarkan uraian data yang dianalisis pada bab sebelumnya, ada beberpa kesimpulan yang dapat dikemukakan yakni:

1. Analisis etnografi yang berhubungan dengan bahasa yang terkandung dalam kumpulan cerpen Galuh Pasar Terapung yang berkenaan dengan bahasa Banjar, antara lain: lindap, tapih bahalai, tilam, huma-huma, lanting, handai taulan, kalambu, dan sebagainya. Kemudian yang berkenaan dengan bahasa Arab, 
antara lain: innalillah, khalifah, dakwah, zikir, shalat, dan sebagainya. Dan yang terakhir adalah yang berkenaan dengan bahasa Inggris, antara lain adalah: pick up, pink, grand opening, close up, dan lain sebagainya,.

2. Analisis etnografi yang berhubungan dengan mata pencaharian yang terkandung dalam kumpulan cerpen Galuh Pasar Terapung, yakni antara lain adalah: polisi, penjaga kuburan, aparat masyarakat, supir ambulance, guru honorer, penjaga sekolah, maling, supir taksi, mamantat, dan lain sebagainya.

3. Analisis etnografi yang berhubungan dengan sistem organisasi sosial yang terkandung dalam kumpulan cerpen Galuh Pasar Terapung, yakni antara lain adalah: presiden, gubernur, bupati, polisi, pambakal, kepala desa, koperasi, dan lain sebagainya.

4. Analisis etnografi yang berhubungan dengan sistem religi yang terkandung dalam kumpulan cerpen Galuh Pasar Terapung, yakni antara lain adalah: pakaian kuning, kain kuning, kalambu kuning, pawang buaya, ritual makhluk besar, merapal mantra, kopi pahit kopi manis, kemenyan, dan lain sebagainya.

\section{DAFTAR RUJUKAN}

Endraswara, Suwardi. 2013. Metodologi Penelitian Sastra. Cetakan Pertama. Edisi Terbaru. Yogyakarta: Center for Academic Publishing Service.

Hapip, Adul Djebar. 2008. Kamus Banjar Indonesia. Banjarmasin: $\mathrm{CV}$ ADITAMA

Imbrahim M. Kasir. KAMUS ARAB INDONESIA, INDONESIA ARAB. Surabaya: APOLLO Surabaya.

Nurgiyantoro, Burhan. 2010. Teori Pengkajian Fiksi.

Yogyakarta: GADJAH MADA UNIVERSITY PRESS.

Pusat Bahasa Departemen Pendidikan Nasional. 2008. Kamus Besar Bahasa Indonesia Pusat Bahasa. Edisi Keempat. Cetakan Pertama. Jakarta: PT Gramedia Pustaka Utama.

Ratna, Nyoman Kutha. 2015. Teori, Metode, dan Teknik Penelitian Sastra. Yogyakarta: PUSTAKA PELAJAR.

Rizka, Nur Cahaya. 2011. Kajian Etografi Banjar Terhadap Kumpulan Cerpen Perempuan yang Memburu Hujan. Skripsi tidak diterbitkan. Banjarmasin: STKIP PGRI Banjarmasin.

Sulistyowati, Endang dan Tarman Effendi Tarsyad. 2015. Kajian Prosa Fiksi. Banjarbaru: Scipta Cendekia. 